\title{
Article \\ Analysis of the Acceptance of Sustainable Practices in Water Management for the Intensive Agriculture of the Costa de Hermosillo (Mexico)
}

\author{
Claudia Ochoa-Noriega, Juan F. Velasco-Muñoz $\mathbb{D}^{\mathbb{D}}$, José A. Aznar-Sánchez * ${ }^{\mathbb{D}}$ and Belén López-Felices $\mathbb{D}$
}

check for

updates

Citation: Ochoa-Noriega, C.;

Velasco-Muñoz, J.F.; Aznar-Sánchez, J.A.; López-Felices, B. Analysis of the Acceptance of Sustainable Practices in Water Management for the Intensive Agriculture of the Costa de Hermosillo (Mexico). Agronomy 2022, 12, 154. https://doi.org/10.3390/ agronomy12010154

Academic Editors: Jorge F. S. Ferreira

Received: 10 November 2021

Accepted: 5 January 2022

Published: 8 January 2022

Publisher's Note: MDPI stays neutral with regard to jurisdictional claims in published maps and institutional affiliations.

Copyright: (C) 2022 by the authors. Licensee MDPI, Basel, Switzerland. This article is an open access article distributed under the terms and conditions of the Creative Commons Attribution (CC BY) license (https:// creativecommons.org/licenses/by/ $4.0 /)$
Department of Economy and Business, Research Centre on Mediterranean Intensive Agrosystems and Agrifood Biotechnology (CIAIMBITAL), University of Almería, 04120 Almería, Spain; claudia08a@hotmail.com (C.O.-N.); jfvelasco@ual.es (J.F.V.-M.); blopezfelices@ual.es (B.L.-F.)

* Correspondence: jaznar@ual.es

\begin{abstract}
Mexico, as many countries, relies on its aquifers to provide at least $60 \%$ of all irrigation water to produce crops every year. Often, the water withdrawal goes beyond what the aquifer can be replenished by the little rainfall. Mexico is a country that has experienced a successful process of regional development based on the adoption of intensive agricultural systems. However, this development has occurred in an unplanned way and displays shortcomings in terms of sustainability, particularly in the management of water resources. This study analysed the case of Costa de Hermosillo, which is one of the Mexican regions in which this model of intensive agriculture has been developed and where there is a high level of overexploitation of its groundwater resources. Based on the application of a qualitative methodology involving different stakeholders (farmers, policymakers, and researchers), the main barriers and facilitators for achieving sustainability in water resources management have been identified. A series of consensus-based measures were contemplated, which may lead to the adoption of sustainable practices in water management. Useful lessons can be drawn from this analysis and be applied to other agricultural areas where ground and surface water resources are overexploited, alternative water sources are overlooked, and where stakeholders have conflicting interests in water management.
\end{abstract}

Keywords: intensive agriculture; water management; participatory assessment; stakeholders; sustainable development

\section{Introduction}

Of the objectives included in the 2030 Agenda of the United Nations, the eradication of poverty and hunger and access to drinking water are the most urgent for the survival of a large part of the population [1]. These objectives are closely related and their fulfilment is threatened by different factors. First, the population is growing much faster than food producers' capacity to respond [2]. It is estimated that the population will increase from 7.7 to 9.7 billion people by 2050 [3]. Furthermore, global economic development has given rise to the expansion of the population segment classified as middle class, which has a higher level of income, generating a modification in consumption patterns due to the evolution of global lifestyles [2]. Consequently, consumer preferences require a greater use of resources, which threatens the sustainability of the production system. It is estimated that in order to satisfy global demand for the year 2050, based on current consumption patterns, the resources equivalent to those of three planet earths would be necessary [4]. In food production alone, it has been estimated that by the year 2050, an increase in production of between 25 and 110\% will be required, depending on the different possible scenarios $[5,6]$.

As a principal supplier, not only of food but also a wide range of raw materials, agriculture plays a prominent role in ensuring food security [7]. In addition to satisfying the growing demand, agricultural production systems must adapt to the consequences of global 
climate change [8]. These consequences include the alteration of rainfall cycles, long periods of drought and imbalances in the supply of water; more frequent and more unpredictable and extreme weather phenomena; and changes in soil humidity, evapotranspiration flows and surface run-off $[9,10]$. The agricultural expansion and intensification taking place over the last few decades has enabled unprecedented growth in food production. However, it has had a severe impact on forest and aquatic systems [11]. Deforestation practices related to agriculture are the world's second largest threat in terms of conservation of biodiversity $[12,13]$, given that approximately three quarters of the world's forests have been lost due to this activity [14].

The main limiting factor for the expansion and intensification of agriculture is the availability of water [15]. Furthermore, as the leading consumer of water resources on a global level, agriculture has reduced the quality and quantity of available water on a global level in recent decades [11,16]. Agriculture uses between 60 and $90 \%$ of the available water, depending on the climate and economic development of the region $[17,18]$. An increase in irrigation to satisfy the growing demand for food will severely affect the availability of water for the natural ecosystems and even human supply [19,20]. According to the 2020 United Nations report on water resources, there are currently 2.2 billion people across the world who have limited access to drinking water [21].

Mexico has become an agricultural power in terms of cultivated area, production and volume of exports [22]. It is also one of the world's principal suppliers of food [23]. The country has an area of 198 million hectares, of which approximately $73 \%$ is used for agricultural activities [24,25]. Agriculture accounts for approximately $4 \%$ of Gross National Product (GNP) [26]. In recent years, the share of Mexican agricultural products in foreign markets has increased, thanks to their quality and variety and the tariff advantages derived from the North American Free Trade Agreement (NAFTA) [27]. Furthermore, the agricultural activity has played a fundamental role in the regional development of Mexico [28]. Approximately $20 \%$ of the country's population is in a situation of food poverty, and 5\% are classified as malnourished [25]. This situation is even more critical in the rural environment, where agriculture represents $50 \%$ of the income of the family $[29,30]$. According to the 2018 report on the evolution of the Sustainable Development Goals (SDGs), $58.2 \%$ of the Mexican rural population lived in a situation of poverty [31]. This figure was as high as $71.9 \%$ among the indigenous population (a total of twelve million people) [31]. It is estimated that the children living in the rural areas have a growth delay of $43.4 \%$, more than double that of the national average of Mexico, with negative effects on motor and cognitive development [32,33].

Mexico is a paradigmatic example of a country which has experienced a successful process of regional development based on the evolution of traditional agricultural models towards modern agricultural systems [28]. However, this development has occurred in an unplanned way and displays shortcomings in terms of sustainability [23,31]. Due to its location and climate conditions, Mexican agriculture is particularly sensitive to the problem of water. Some of the principal agricultural regions suffer from serious deficit problems in their water bodies. Furthermore, this country is located in an area particularly vulnerable to the impacts of global climate change, most of all in terms of water resources and agricultural management $[21,25]$. In addition, this development has been based on the use of poor environmental management practices, fundamentally with respect to the management of water resources and the unequal distribution of land and infrastructures [23,29]. As a result, this country is a perfect laboratory for studying the agricultural development experienced by developing countries. Therefore, the objective of this study is to analyse one of the Mexican regions (Costa de Hermosillo) that has experienced an agricultural modernisation process more intensely, based on the overexploitation of its groundwater resources. Furthermore, it seeks to identify the principal barriers and facilitators for obtaining sustainability in the management of water resources in this region. Finally, it attempts to find a series of measures that will contribute to the adoption of sustainable practices in water management in the agricultural region studied. 
The state of Sonora holds the third position in terms of the value of national agricultural production, with more than 15327 million pesos (748 million US\$), accounting for 13.7\% of the national total and a cultivated area of 411,090 hectares. The Costa de Hermosillo represents $12 \%$ of the total surface area with 49524 hectares and $23.2 \%$ of the total value of production with 3556 million pesos (173 million US\$) [34]. The agriculture of the Costa de Hermosillo has evolved from traditional production systems based on corn, wheat and cotton crops to an intensive agricultural model based on the use of new technologies and innovation processes in production, storage and distribution [35,36]. This transformation began with the coming into force of the North American Free Trade Agreement (NAFTA) in 1994 [27]. Currently, the predominant crops are tomatoes, pumpkins, asparagus, green chili, melon, citrus fruits, cucumber, watermelon, grapes and walnuts, which are mainly exported. The state has a vast hydraulic infrastructure made up of a system of dams and pipelines for irrigation, which is carried out principally through gravity and flooding [37].

The Colonisation Decree of 1949 establishes three forms of land ownership; small owners, settlers and ejido members [38]. This ownership structure gave rise to a concentration of water as a result of the prior concentration of land [38]. The small owners have the private ownership of a farm for which the volume of groundwater used for irrigation cannot exceed 100 ha based on Clause XV of Article 27 of the constitution. In practice, this condition is not fulfilled [39]. The small owners have farms of between 200 and 400 ha. Furthermore, different members of the same family own farms resulting in the formation of large family farms with thousands of hectares [40]. The settler sector is formed by 66 settler associations, fruit of the migration from other regions. These associations were granted the right to collectively farm the low-quality land close to the coast, which were affected by the salinisation due to the seawater intrusion into the aquifer [41]. These lands have now been abandoned and the settlers work as day labourers for the small owners or have emigrated, mostly to the United States [41]. Finally, the ejido sector is made up of 28 scattered rural villages which were established from 1964 [42]. The crop area of the ejidos is of a low quality and is leased to the small owners or used for subsistence production in small farms by the ejido members, who sell their produce directly to consumers [39].

The use and exploitation of the groundwater is regulated through the National Water Act of 1992 (LAN). Article 3 of this Act allows the exploitation of the aquifers for the use of the resources through an individual license or concession granted to the private farmers by the National Water Commission (CONAGUA), which must be registered in the Public Registry of Water Rights (REPDA) [43]. Article 4 provides that the authority and administration of the aquifer correspond to the Federal Executive Body, which exercises these responsibilities directly or through the CONAGUA which, in turn, must be made up of a technical board and should have close ties with the Basin Councils of the respective water basin body responsible for monitoring, administrating or managing the use of the water resources [43].

Table 1 presents a selection of previous literature on the adoption of sustainable practices in Mexican agriculture. Among these works, the study of soil conservation and water resource management are highlighted as priority issues. Of particular relevance is the study of traditional knowledge in subsistence agricultural production, as a basis for the development of the most vulnerable rural populations. For more detailed information, see the work of Ochoa-Noriega [23], a bibliometric review of sustainable agriculture in Mexico. 
Table 1. Previous literature on sustainable agricultural management in Mexico.

\begin{tabular}{|c|c|}
\hline Title & Author and Year \\
\hline $\begin{array}{c}\text { Adoption of phytodesalination as a sustainable agricultural practice for improving } \\
\text { the productivity of saline soils }\end{array}$ & Lastiri-Hernández et al. 2021 [44] \\
\hline $\begin{array}{c}\text { Analysis of energy consumption for tomato production in low technology } \\
\text { greenhouses of Mexico }\end{array}$ & Ramirez-Arias et al. 2020 [45] \\
\hline $\begin{array}{c}\text { Temporal Dynamics of Rhizobacteria Found in Pequin Pepper, Soybean, and } \\
\text { Orange Trees Growing in a Semi-arid Ecosystem }\end{array}$ & Diaz-Garza et al. 2020 [46] \\
\hline $\begin{array}{c}\text { The Use of Water in Agriculture in Mexico and Its Sustainable Management: } \\
\text { A Bibliometric Review }\end{array}$ & Ochoa-Noriega, et al. 2020 [23] \\
\hline $\begin{array}{l}\text { Sustainability prospective for water resources in Northwestern Mexico: Use of } \\
\text { recycled concrete for Agricultural purpose water supply }\end{array}$ & Gutiérrez-Moreno et al. 2020 [47] \\
\hline $\begin{array}{c}\text { Ecological, Cultural, and Geographical Implications of Brahea dulcis (Kunth) Mart. } \\
\text { Insights for Sustainable Management in Mexico }\end{array}$ & Pérez-Valladares et al. 2020 [48] \\
\hline $\begin{array}{l}\text { The sustainable cultivation of Mexican nontoxic Jatropha curcas to produce } \\
\text { biodiesel and food in marginal rural lands }\end{array}$ & Pérez et al. 2019 [49] \\
\hline Sustainability and environmental management in the Mexican vegetable sector & Padilla-Bernal et al. 2019 [50] \\
\hline $\begin{array}{l}\text { Vulnerability, innovation and social resilience in the maize (Zea mays L.) } \\
\text { production: The case of the conservation tillage club of chiapas, Mexico }\end{array}$ & Díaz-José et al. 2018 [51] \\
\hline $\begin{array}{l}\text { The myth behind sustainable African palm crop. Socio-environmental impacts of } \\
\text { palm oil in Chiapas, Mexico }\end{array}$ & León et al. 2017 [52] \\
\hline $\begin{array}{l}\text { TEK and biodiversity management in agroforestry systems of different } \\
\text { socio-ecological contexts of the Tehuacán Valley }\end{array}$ & Vallejo-Ramos et al. 2016 [53] \\
\hline $\begin{array}{c}\text { Degree of sustainability of rural development in subsistence, intermediate, and } \\
\text { commercial farmers, under an autopoietic view point }\end{array}$ & García et al. 2009 [54] \\
\hline
\end{tabular}

\section{Materials and Methods}

This study seeks to analyse a complex agricultural system that incorporates different types of agents with conflicting objectives. Moreover, it aims to reach a consensus-based proposal for the sustainable management of the water resources available in the system. In order to fulfil this objective, a participatory qualitative methodology has been developed. This type of research provides a more in-depth understanding of the topic of study, the variables involved, the relationships established between them and identifies the critical points, which enables us to appreciate the interactions in complex systems, such as the case of water management systems [55,56]. Finally, even though the potential for generalisation of case studies may be limited, these types of studies can offer a range of possible alternatives to test in similar contexts and can constitute a model with which to reach consensus-based measures in other contexts [57].

\subsection{Case Study}

The study was conducted in the Costa de Hermosillo, in the northeastern region of Mexico, in the central coastal plain of the state of Sonora (Figure 1). The Hermosillo Coast stretches $100 \mathrm{~km}$ in a straight line between the city of Hermosillo and Bahía de Kino, on the shores of the Gulf of California. This area has a semi-arid climate, with an annual average rainfall of less than $100 \mathrm{~mm}$, concentrated in the summer months, an annual average temperature of $24{ }^{\circ} \mathrm{C}$ which can fluctuate between a maximum of $47^{\circ} \mathrm{C}$ and a minimum of $-3{ }^{\circ} \mathrm{C}$, and high solar radiation [55].

The Costa de Hermosillo corresponds to irrigation district 051 created in 1953 for the management of its agricultural water resources [58]. This district is supplied by the water basin of the Sonora and Bacoachi rivers, which have irregular flows, a low volume and high infiltration [59]. The principal source of water for irrigation is underground, being one of the largest pump irrigation districts in the country [41]. In 1980, a total of 498 wells were drilled exclusively for agricultural use, accounting for $90 \%$ of the available water for this sector $[60,61]$. The main aquifer of the system is identified as 2619 . This aquifer has an average annual recharge of $250 \mathrm{hm}^{3} /$ year and an average extraction of $346 \mathrm{hm}^{3} /$ year [41]. As a result, there is an average annual deficit of $96 \mathrm{hm}^{3} /$ year, which 
has translated into a reduction in the total volume of water, giving rise to a process of water intrusion, contaminating the available freshwater [58]. It has been declared as one of the 17 aquifers with saltwater intrusion and as one of the 115 overexploited aquifers on a national level, having the highest deficit of the 61 existing in the state of Sonora [62]. As a consequence of the water resource situation, farms that are unproductive due to the salinity of the soil have been abandoned. The concession of new farms is unfeasible and the rivalry between the different users of water for irrigation has increased.

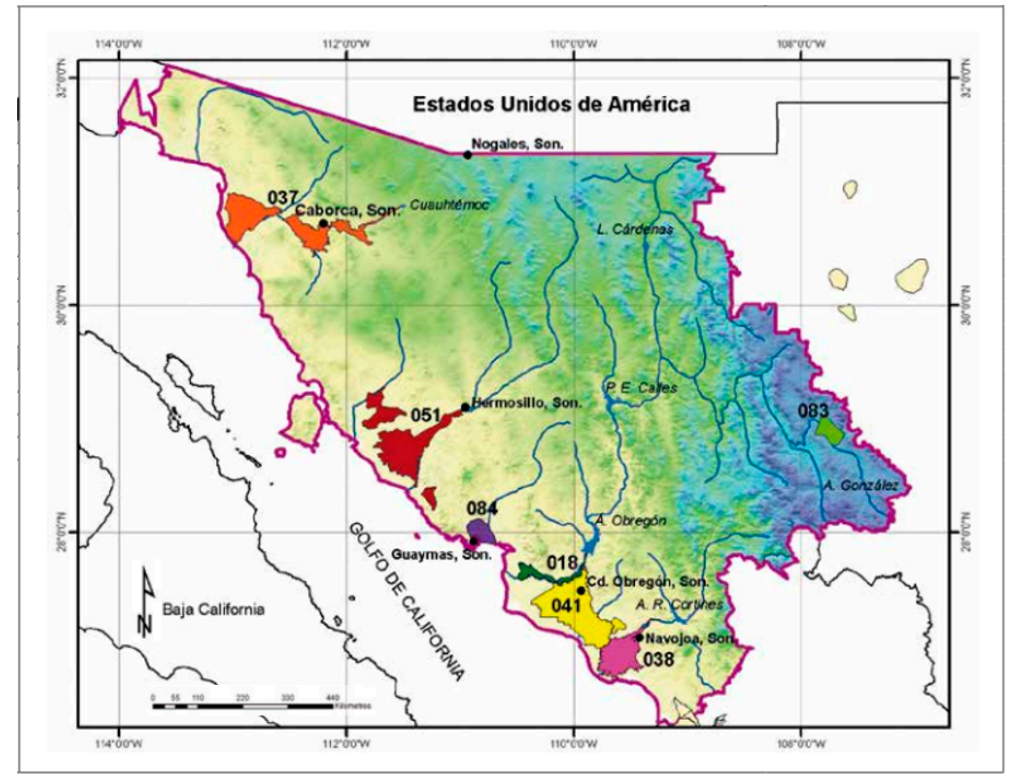

Figure 1. Location of irrigation districts of the basin organisation: Northwestern Mexico. District 051 Costa de Hermosillo, Sonora, Mexico [34]. Sonora borders the American states of Arizona and New Mexico.

The administration and management of the use of the groundwater in this area is carried out through a group license granted to the User's Association of District 051 (AUDR, 051) [63]. This has led to a greater concentration of resources, predominantly by the private farmers who have been able to afford the pumping costs and the investments necessary to meet the standards established in the destination countries for exported crops [40].

\subsection{Methods}

This study has used a series of methods aiming to compile both primary and secondary information, based on the different development stages of the research. First, a literature review was carried out in order to establish the conceptual framework to guide the rest of the process. Second, a series of interviews with experts was conducted on the topic in order to identify the possible management alternatives and principal barriers and facilitators for their adoption. Finally, a workshop was undertaken to assess the different points of view of the groups of stakeholders involved and to draw up a consensus-based proposal for the adoption of the measures to apply.

As a starting point, the literature review is considered as a necessary task in all research studies [63]. The objective of this methodological tool is to identify the most relevant contributions in which the concepts and theories that should be applied are defined and to structure the research problem [64]. In this way, the context is obtained and the theoretical and conceptual foundation is established based on previous studies on the topic and case studies [65]. Furthermore, the experience gained in other analyses enables us to identify the principal variables that intervene in the case study and to delimit their structure of relations, allowing us to establish starting hypotheses [66]. The literature review included both scientific and grey literature. In the first case, the main literature repositories were 
used, both in English and Spanish, such as Dialnet, Scielo and Scopus. The grey literature included documents published by official sources such as the National Water Commission, the Official Journal of Mexico, or the United Nations.

The interviews are more or less structured conversations which generate interaction between the parties involved with the objective of obtaining knowledge [67]. As an exploratory method of research, the interviews seek to find new aspects and develop research questions regarding topics that are not clearly defined [68]. In-depth interviews generate an exchange of ideas through interactive conversations with stakeholders with the objective of establishing a close relationship between the participants and the interviewer in order to obtain exhaustive and significant responses [69]. These interviews are not structured or semi-structured. They are based on a script with a series of open questions which are answered during the interview [70]. The method of sample selection was snowballing. This non-probability sampling technique is based on the fact that a small set of study subjects recruits future subjects from among their acquaintances. In this way, the statistical sample grows according to a snowball or domino effect [63]. There were two advantages to using this methodology. On the one hand, it made it possible to contact the right person for the purpose of the study. On the other hand, it allowed for a good predisposition on the part of the interviewee by having the recommendation of another person. A total of seven experts participated: two from academia, two from business, two from administration and one technical professional. The experts were selected from among persons of recognised prestige within the agricultural sector for their leadership position within a relevant organisation (public or private), number of scientific publications, and/or years of experience. A script for the open-ended interview is included in the supplementary material (Supplementary Material 1).

Finally, a workshop was conducted in order to fulfil the objective of designing a management proposal agreed by all of the parties. This methodology enables different stakeholders to collaborate in order to share their knowledge on the theme of study [71]. The workshop is a tool that allows the knowledge from different fields to be synthesised and assessed and conclusions to be drawn [72,73]. Furthermore, it can reinforce the connection between the researchers and policymakers, enabling the development of knowledge that can serve as a base with which to generate policies [74]. The use of this methodology seeks to present all of the knowledge obtained in the previous stages of the research, to incorporate the different points of view of the stakeholders and to reach a consensusbased proposal which allows the adoption of sustainable management practices. In the previous interview phase, farmers, policymakers and researchers were highlighted as the main stakeholder groups. In the case of farmers, it refers to private owners, as they are the main decision-makers in land management. The policymakers are responsible for setting policies and regulations, as well as incentives to encourage behaviour. Researchers are the main providers of knowledge. Through the snowballing procedure, an equal number of members were selected from each group, so that there would be a homogeneous representation of the different groups. In this way, all groups are in the same position to reach an unbiased consensus.

In order to establish a hierarchy with respect to the level of influence of the different factors identified regarding the adoption of each of the practices proposed, a workshop was carried out incorporating the most representative interested parties. The workshop was attended by representatives of farmers (private landowners), policy makers, and researchers. Farmers (private landowners) are the ones who are mainly affected by the proposed measures and who must carry out the practice. Policy makers need to regulate and set incentives to implement the practices. Finally, researchers are in charge of generating the necessary knowledge to guide the whole process. Each of these groups contributed with a total of three participants, so that the different interests and points of view were considered equally. 


\section{Results}

The most urgent problem to be addressed, according to the perception of stakeholders, is the scarcity of water resources and the overexploitation of aquifer Costa de Hermosillo (designated in the National Water Law as aquifer 2619), caused by the development of agricultural activities on the Hermosillo Coast. Therefore, different practices have been identified to increase the supply of water for irrigation through diversification of sources. Of all the possible alternatives, two sustainable practices capable of contributing to the recovery of the aquifer through the reduction of abstractions have been selected:

- The harvesting and storage of rainwater (hereinafter P1-practice 1). Given the characteristics of the area of study, the majority of the rainwater is lost through evaporation or run-off. Rainwater can constitute a low-cost resource, requiring only the installation of a small infrastructure to enable its channeling and storage $[75,76]$. Another relevant aspect is the monitoring of rainfall in order to plan the water needs based on the harvesting of annual rainfall for the crops [75]. This rainfall monitoring should include the total duration of rainfall, the intensity (volume of rain per unit of time) and frequency (the number of precipitations in a given time and with certain characteristics). The compilation of these data enables the design of a climate prediction model for developing technical processes of infrastructures that control the harvesting and storage of rainwater for agricultural use.

- The desalination of seawater (hereinafter P2-practice 2). Desalination is a process in which the salts are eliminated from the water. Although there are different methods of desalination, the most commonly used is reverse osmosis. In this process, the water is conducted through semi-permeable membranes under pressure. The salts are retained in the membranes, while the water molecules circulate.

Five principal barriers and five facilitators were identified for adopting sustainable practices in the management of irrigation water in the area of study (Figure 2). These factors were classified into three different groups: institutional, technical and socio-economic. Barriers include (i) the lack of regulation and the high level of noncompliance with existing legislation; (ii) the current land ownership structure and the concentration of water use rights; (iii) the lack of technical knowledge regarding the proposed innovations; (iv) the low level of rainfall; and (v) the lack of environmental knowledge of farmers. The main facilitators are (i) the existence of institutional incentives for the adoption of sustainable practices; (ii) the continuous process of technological innovation in which the sector is immersed; (iii) the positive disposition of farmers towards technical change; (iv) the collaborative relationships between the different actors; (v) the sector's financing capacity.

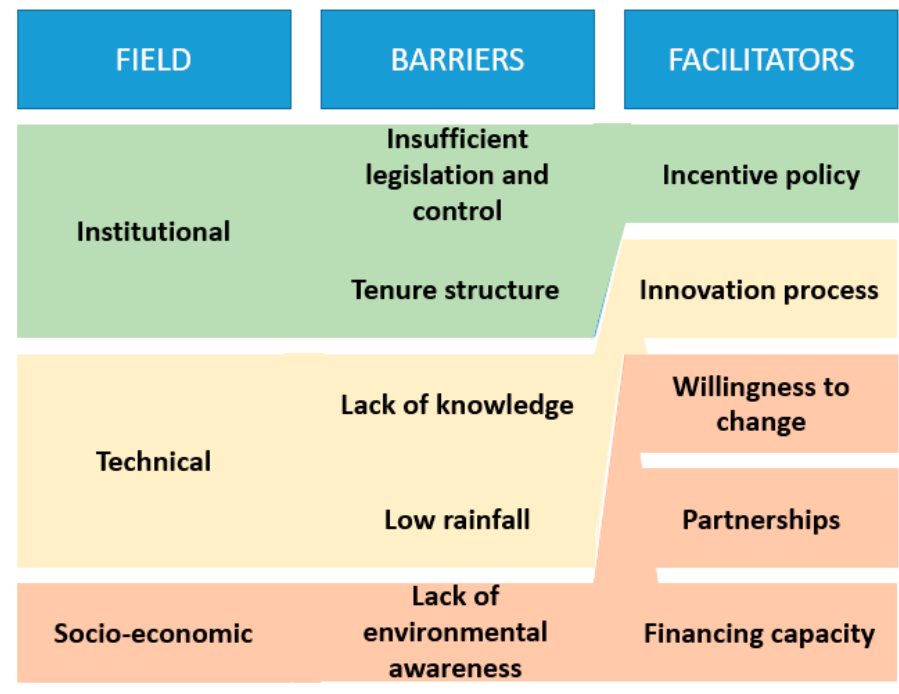

Figure 2. Main barriers and facilitators for the adoption of sustainable practices. 
Figure 3 illustrates the results regarding the perception of each group of stakeholders in terms of the level of influence of each barrier to adopting the proposed practices. In this case, the farmers and policymakers show a higher level of agreement. The two groups coincide in considering that the principal barriers to adopting the rainwater harvesting systems are the lack of knowledge of the different aspects of the infrastructure, capacity and return on investment, and the erratic behaviour of the rainfall, which makes it difficult to forecast the water needs at any given time, particularly with the impact of climate change. Meanwhile, the researchers indicated a high degree of noncompliance with the applicable regulations, the low level of environmental awareness among the farmers and policymakers, and the power of the farmers to concentrate the water rights derived from the land ownership regime.

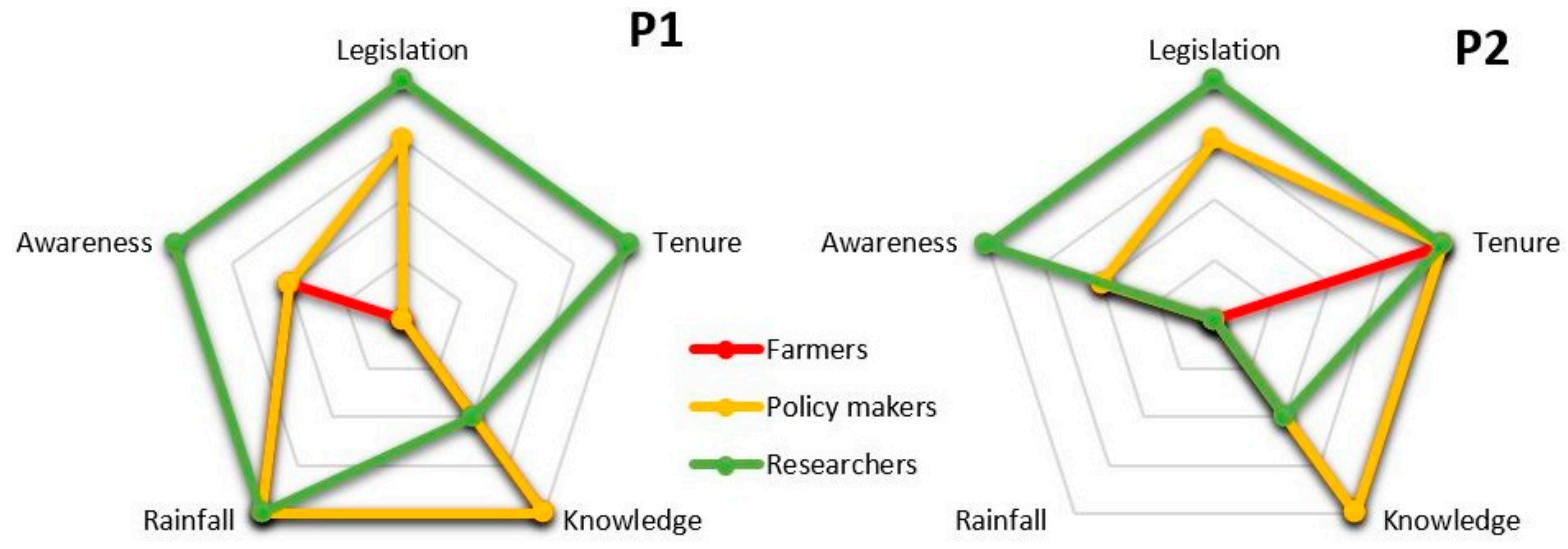

Figure 3. Main barriers to the adoption of sustainable practices by group. P1 (harvesting and storage of rainwater, practice 1); P2 (desalination of seawater, practice 2).

With respect to the installation of the desalination plant in the area of study, the three groups identify the ownership regime as the principal obstacle. However, there are different opinions with respect to the reason for this. The researchers and policymakers believe that the negotiating capacity of the farmers can impose objectives to increase the crop area instead of mitigating the overexploitation of the aquifers. On the other hand, the farmers highlight the need for finance from the administration, given that the group of farmers is very small and cannot undertake such a large investment which would be borne by a small number of entrepreneurs. In this case, the rainfall factor is not relevant, as the desalination of seawater does not depend on climate factors. The principal discrepancy regarding the different barriers resides in the fact that the researchers continue to denounce a lack of compliance with the regulations and environmental awareness. The farmers and policymakers claim that there is a gap in the knowledge on a local level regarding the impact of the use of desalinated water. In this respect, the researchers argue that there is sufficient research in favour of the use of this technology, although they acknowledge that more information on a local level is required even though previous studies have been carried out $[77,78]$.

Concerning the factors acting as facilitators for the adoption of the proposed practices, the results are shown in Figure 4. In this case, the responses are more similar as they refer to both management alternatives. With regards to rainwater harvesting, the three groups indicate that the modernisation of agriculture experienced over the last few decades and the disposition of the farmers in following the continuous improvement process are the principal pillars for the adoption of these practices. The policymakers indicated that the administration has already made different proposals to encourage technological development in the region which should serve as an incentive to adopt these practices. Meanwhile, the researchers surveyed in this study support that the sector has sufficient financing capacity to cover the investment necessary for the installation of rainwater 
harvesting systems. However, with respect to the installation of the seawater desalination plant, the researchers surveyed in this study do not believe that the prior innovation process will be so positive, given that, to date, the sector has not made an investment of such a scale, so prior experience will not be useful for managing this new additional resource.

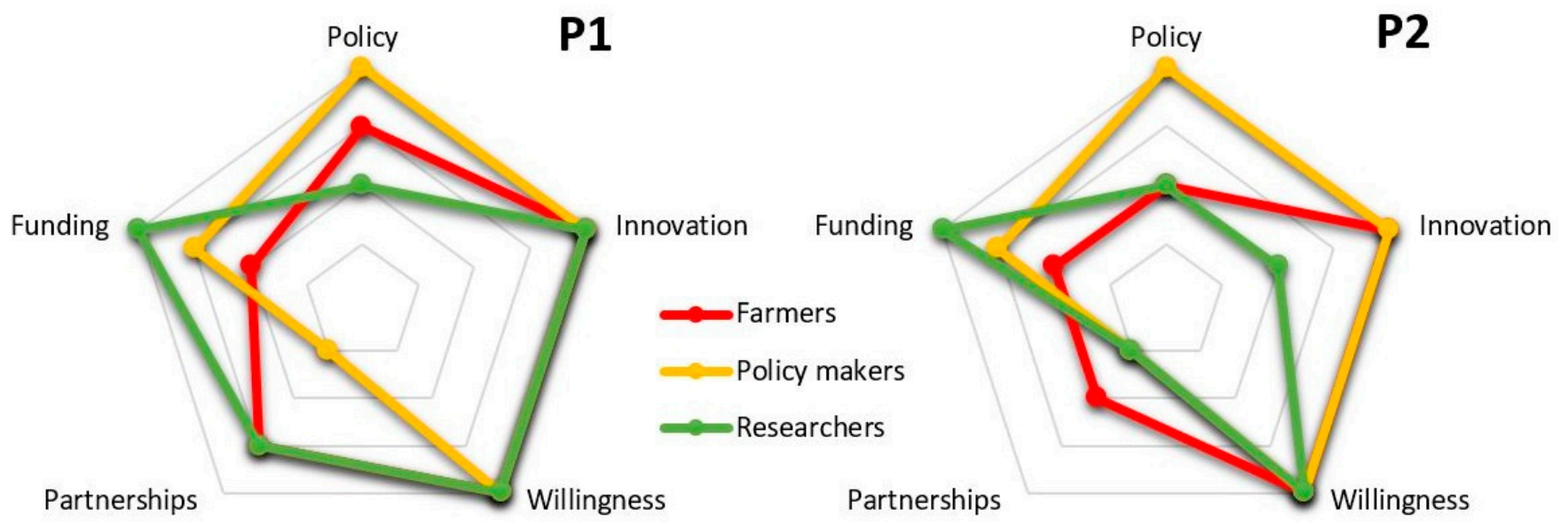

Figure 4. Main facilitators for adopting sustainable practices by group. P1 (harvesting and storage of rainwater, practice 1); P2 (desalination of seawater, practice 2).

As a result of the workshop and sharing the different points of view, the different groups represented established a series of common points that serve as a guide to design an action plan for the adoption of the different practices proposed. This action plan is based on three pillars. Firstly, commitment to the gradual reduction in groundwater extraction from the aquifer as new water sources become available. Secondly, closer collaboration and communication between the different groups to obtain and disseminate knowledge and to improve the level of environmental awareness. Finally, the design of a public-private financing strategy in order to undertake the investment necessary for the development of the proposed projects.

First, the three groups (farmers, policy makers, and researchers) agree that the situation of the aquifer is unsustainable and threatens the continuity of the agricultural activity in the area in the medium to long term, which is the case of other coastal territories of this region. To address this problem, the farmers consider as positive the reduction of the extraction of groundwater for irrigation until the aquifer has been recharged and other alternative water sources become available for crop irrigation. In this way, the crop areas will not be extended until the water supply is expanded and the possible surplus will be used for recharging the underground water bodies.

Second, to guarantee that this commitment is fulfilled, all of the groups agree that it is necessary to work together to design the best strategy for implementing the new processes. On the one hand, updated technical knowledge is required that will enable the optimisation of the investment. This knowledge should be obtained directly on the farms; so, close collaboration between researchers and farmers is required. Furthermore, the policymakers should provide coverage and get involved in all of the levels for the process to be successful. Therefore, there should be a three-way collaboration. On the other hand, the level of environmental awareness regarding the different processes related to agriculture should be improved, not only in terms of water management, but also those referring to the conservation of the soil and air pollution. These factors give rise to a better conservation of the water resources. Finally, a comprehensive management of the agricultural ecosystem is the only way to maintain the means of subsistence for future generations.

Third, undertaking the proposed investments, particularly the seawater desalination plant, requires a considerable volume of investment. According to the consensus reached, given the general interest in the conservation of the underground water bodies, while maintaining an agricultural production that supports a good part of the population in the 
area of study, the best option is the development of a joint financing project between the administration and the entrepreneurs. In this way, the negative externality (negative result of agricultural activity not incorporated in its costs) generated with the overexploitation of the aquifer by the farmers would be internalised and the farmers would be compensated by the positive externality (positive result from agricultural activity not incorporated in its profits) generated by the creation of jobs and the securing of the rural population.

\section{Discussion}

Among the different aspects that condition the sustainability of the agricultural productive model on the Hermosillo Coast, water supply is a pressing structural problem. This situation is aggravated by the impact of global climate change on temperature and rainfall patterns. Therefore, all actors involved agree that measures must be taken. This is mainly because producers are already aware of the decline in crop productivity due to high groundwater salinity, that is the only source of water for irrigation. Carrillo-Huerta and Gómez-Bretón [78] conducted a study on the evaluation of irrigation technology in a district with an overexploited aquifer in Puebla, Mexico. Among their results, they identified farmers and policy-makers as the key stakeholder groups in water resources management. These results are similar to those obtained in the present study. However, in their case, the path chosen to improve the management of water resources and the state of the aquifer was on the demand side, whereas in this study the focus was on increasing the supply of the resource. Dévora-Isiordia et al. [79] estimated an increase of one tonne per hectare in sorghum production by using desalinated water $(0.1 \mathrm{dS} / \mathrm{m})$ instead of brackish well water $(10.3 \mathrm{dS} / \mathrm{m})$ in the Yaki Valley, Sonora. In addition, these authors have tested the technical and economic feasibility of using desalinated water in the study area by comparing different technical developments [80]. Their results show that the price of desalinated water (obtained from brackish water) was 0.6 US\$/1000L, while for seawater it was 1.2 US\$/1000L. Other studies show that desalinated water can be more costly in monetary and energy terms when compared to other sources. A report comparing the cost of alternative water supply and efficiency options in California [81] cited that desalinated water was the most expensive source of water to groundwater at $2100 \$$ /acre foot for large projects and 2800-4000\$/acre foot for smaller projects. The cheapest was captured stormwater (590\$/acre foot). The second least expensive was desalinized brackish water (requires less energy than to desalinate seawater). It is shown that reused water could be a more economical alternative source than desalinated seawater. The reason why reused water was not initially included as an alternative in this study was that in the study area there are 44 water treatment plants for reuse for industrial purposes and irrigation of gardens and green areas. Thus, its availability for agriculture is lower. However, the authors of this work propose this as a future line of research due to the fact that some of these plants are underused, the price differential indicated, and the improvement in the circularity of urban water that reuse would entail.

Rainwater harvesting systems, adapted to different types of agricultural practices, are widely developed, and have demonstrated their viability to supplement irrigation in semi-arid environments [76]. Loera-Alvarado et al. [82] conducted a study to test the suitability of runoff water for agricultural use in the State of San Luis Potosí. From their results, they concluded that the runoff water stored in earthen dams is of excellent quality for agricultural use (even in soils with very low permeability) and to grow crops sensitive to salinity and sodium. However, they indicate that it is necessary to assess water suitability in conjunction with the soil-climatic characteristics of the site in order to establish an appropriate management system for each specific case. This would be especially necessary in the case of combining runoff water with desalinated seawater, based on the proposal of this study. López-Hernández et al. [83] compare a rainwater harvesting system with groundwater abstraction for domestic and agricultural use in a municipality in the State of Tlaxcala, Mexico. Their results show that rainwater can be more economically viable than ground-water abstraction when demand is low. A future line of research could compare 
the demand for the two types of water in the study area to establish the tipping point in the use of these two resources and influence demand control to minimise water use from the aquifer.

As already mentioned, in the area of study there is a regulation for the concession of the rights to extract groundwater for irrigation, establishing a maximum limit per farmer [39]. These rights are obtained through the User's Association of District 051 (AUDR, 051), up to the maximum allowed by law [63]. However, in practice this condition is not fulfilled. There is a lack of control in terms of the area that is irrigated with groundwater and the amount of water extracted by each concessionaire. On the other hand, the ownership structure of the land has enabled a small group of owners to control large areas [40]. This has given rise to the concentration, in parallel, of the water rights, and has relegated a large part of the population in the area to the role of day labourer. This, in turn, bestows a high degree of negotiating power to the private owners, with respect to the proletariat and the administration, given that their decisions have important repercussions on an environmental, economic and social level for the whole region. From a technical perspective, there is a lack of knowledge on the impact of the adoption of the practices proposed, due to their innovative nature in the area of study [84]. Furthermore, the scarcity of rainfall is a factor to consider, particularly in the case of the practice of rainfall harvesting. In the case of this specific practice, the development of scenarios to evaluate the technical and economic feasibility of the investment is much more relevant. Finally, from a social perspective, the short and medium-term economic criteria play a prominent role in decisionmaking. Conversely, the main social and environmental impacts are seen in the medium and long term [85]. Social impacts include inequality, job insecurity and deterioration of health, especially for the most vulnerable people [32]. Environmental impacts include the deterioration and depletion of water bodies, the transformation of the landscape, and infertility of the soil [6]. In this respect, there is a low level of awareness of the concept of sustainability among farmers. For their part, the labourers do not have the capacity to influence the decisions of the landowners. They receive low wages, which they supplement with subsistence farming on small, unproductive plots of land. In many cases, they are forced to migrate to improve their living conditions in the USA. Aznar-Sanchez et al. [86] studied the use of desalinated seawater as a measure to increase irrigation water supply and improve the sustainability of an overexploited aquifer in Spain. In their case, the main barriers on the farmers' side were the low level of knowledge about the impact of using this type of water, the increased costs (e.g. due to increased fertiliser use) and the price of water. These last two factors were not identified by the stakeholders in the present study.

Despite these barriers, the area of study has a series of facilitators for the adoption of sustainable practices in the management of water for irrigation. On the institutional level, there is a willingness to offer economic and technical consulting incentives for the adoption of technological innovation, leading to an improvement in exports, all under the umbrella of NAFTA. From a technical perspective, and also since the entry into force of NAFTA, the Costa de Hermosillo has experienced a process of innovation, on both a technological and organisational level [80]. The success of this process has generated great interest in continuous improvement among the farmers. Furthermore, during this period, ties have been established between the farmers through the official bodies and through professionals promoting common interests, such as water management or the marketing of products [39]. Carrillo-Huerta and Gómez-Bretón [78] identified technical assistance as the main contribution of public managers to the adoption of sustainable irrigation practices. On the farmers' side, these authors found that associationism around irrigation communities is the main facilitator towards sustainable management that allows aquifer recovery. In the same way, there is close contact between the agricultural business organisations and the Public Administration. These relationships constitute facilitators when designing legislative proposals and providing resources. Finally, as a result of the exporting activity and its attractiveness for investment, there is sufficient financial capacity to carry out the investments necessary to improve the agricultural production sector in the area of study, 
provided that a return on the investment can be gained. Carrillo-Huerta and GómezBretón [78] identified water price as a determining factor in irrigation management in their study from the demand side. This factor has not been pointed out by the stakeholders in our study from the supply side perspective. Aznar-Sanchez et al. [86] identified the possibility of crop diversification and the lack of availability of other alternative sources as the main facilitators for the use of desalinated seawater for irrigation.

Carrillo-Huerta and Gómez-Bretón [78] point out that the lack of consensus in the design and planning of irrigation management measures is the main reason for the current state of deterioration of the aquifer, the result of overexploitation. Therefore, although the proposal made in this paper may be ambitious, having the agreement of the main stakeholders is a positive starting point. The project to build a seawater desalination plant implies the mobilisation of a large amount of resources, not only for the desalination facility, but also for the channelling and transport of water. On the other hand, in 2017, the governor of the state of Sonora, Claudia Pavlovich, led a proposal for the construction of a desalination plant with a capacity of $6,307,200 \mathrm{~m}^{3}$ per year devoted to human consumption [87]. This project has not yet been implemented. However, it is proof that the proposal made in this paper has broad support and the backing of the political class.

Finally, it should be noted that the main limitation of this study is its exploratory nature and the qualitative information on which it is based. Therefore, the development of a broad stakeholder survey is proposed as a future line of research. The purpose of this survey would be to verify the real support of all stakeholders for the proposal, as well as to identify any possible conflicting points that may be detected.

\section{Conclusions}

The objective of this study is to elaborate a proposal to improve the management of the water resources of the Costa de Hermosillo which would be able to: (i) improve the situation of overexploitation of the underground water bodies, (ii) contribute to the sustainability of the agricultural activity in the area, and (iii) reach a consensus between the different parties involved in order to guarantee the success of its implementation.

The results show that the main concern for different stakeholders to ensure the sustainability of an agricultural system in a semi-arid environment is the availability of water. Technology offers a variety of alternatives to try to increase water supply through sources other than overexploited water bodies. In systems based on the use of groundwater with seawater intrusion problems, alternative water sources such as desalinized seawater, rainwater, brackish water, and reclaimed municipal water are potential alternative sources for groundwater and surface waters.

The results also show that the principal driving factors for adopting innovations in the management of agricultural irrigation are the existence of institutional incentives for adopting sustainable practices; the continual process of technological innovation in which the sector is immersed; the good disposition of the farmers towards technical change; the collaboration relationships between the different stakeholders; and the financing capacity of the sector. The principal elements that hinder the adoption of these practices are the lack of regulation and the high level of non-compliance with the legislation in force; the structure of the current land ownership and the concentration of the water use rights; the lack of technical knowledge pertinent to the innovations proposed; the low level of rainfall; and the lack of environmental knowledge of the farmers.

The principal contribution of this study is a proposal designed by the farmers, policymakers and researchers of the area to evaluate the implementation of rainwater harvesting systems and the construction of a seawater desalination plant. This proposal is based on three pillars of action: (i) the reduction of extractions, (ii) continuous cooperation and (iii) public-private financing. These pillars constitute the priority lines of work for stakeholders to carry out the plan designed to improve sustainability in the use of water resources for irrigation. Therefore, a strong commitment from all stakeholders in these three areas of action is essential. Furthermore, given that the concentration of land ownership in turn 
leads to a concentration of water use rights, it would be desirable to update the forms of water governance in a way that it decouples land use from water use.

Supplementary Materials: The following supporting information can be downloaded at: https: //www.mdpi.com/article/10.3390/agronomy12010154/s1. Supplementary Material 1: Analysis of the acceptance of sustainable practices in water management for the intensive agriculture of the Costa de Hermosillo (Mexico).

Author Contributions: Conceptualization, C.O.-N., J.F.V.-M., J.A.A.-S. and B.L.-F.; Formal analysis, C.O.-N. and J.F.V.-M.; Investigation, C.O.-N.; Methodology, C.O.-N., J.F.V.-M., J.A.A.-S. and B.L.-F.; Project administration, J.A.A.-S.; Supervision, J.F.V.-M. and J.A.A.-S.; Validation, J.F.V.-M., J.A.A.-S. and B.L.-F; Writing—original draft, C.O.-N.; Writing—review \& editing, J.F.V.-M., J.A.A.-S. and B.L.-F. All authors have read and agreed to the published version of the manuscript.

Funding: This research received no external funding.

Acknowledgments: This research was partially supported by the Spanish Ministry of Economy and Competitiveness and the European Regional Development Fund by means of the research project ECO2017-82347-P, and from Junta de Andalucía and FEDER aid (project P18-RT-2327 and project UAL-2020-SEJ-D1931, Consejería de Transformación Económica, Industria, Conocimiento y Universidades). And by the FPU19/04549 Predoctoral Contract to Belén López-Felices.

Conflicts of Interest: The authors declare no conflict of interest.

\section{References}

1. Koren, O.; Bagozzi, B.E.; Benson, T.S. Food and water insecurity as causes of social unrest: Evidence from geolocated Twitter data. J. Peace Res. 2021, 58, 67-82. [CrossRef]

2. Oberle, B.; Bringezu, S.; Hatfeld-Dodds, S.; Hellweg, S.; Schandl, H.; Clement, J.; Cabernard, L.; Che, N.; Chen, D.; Droz-Georget, H.; et al. Global Resources Outlook 2019: Natural Resources for the Future We Want. A Report of the International Resource Panel; United Nations Environment Programme: Nairobi, Kenya, 2019. Available online: https: //www.resourcepanel.org/file/1161/download?token=gnbLydMn (accessed on 12 July 2021).

3. United Nations Department of Economic and Social Affairs Population Division (UNDESA). Probabilistic population Projections Based on the World Population Prospects: The 2019 Revision. New York, USA. 2019. Available online: https:/ / population.un. org/wpp (accessed on 12 July 2021).

4. Ceratti, M. Dos Planetas Más Para Poder Vivir En Este; World Bank: Washington, DC, USA, 2016. Available online: https:/ /www. bancomundial.org/es/news/feature/2016/08/09/objetivo-desarrollo-sostenible-ods-12-consumo (accessed on 12 July 2021).

5. Hunter, M.C.; Smith, R.G.; Schipanski, M.E.; Atwood, L.W.; Mortensen, D.A. Agriculture in 2050: Recalibrating targets for sustainable intensification. Bioscience 2017, 67, 386-391. [CrossRef]

6. Laurett, R.; Paço, A.; Mainardes, E.W. Sustainable Development in Agriculture and its Antecedents, Barriers and ConsequencesAn Exploratory Study. Sustain. Prod. Consum. 2021, 27, 298-311. [CrossRef]

7. Velasco-Muñoz, J.F.; Aznar-Sánchez, J.A. The economic valuation of ecosystem services in the agroecosystems in Spain: Conceptual framework and methodology. Pecvnia 2016, 22, 75-93. [CrossRef]

8. Velasco-Munoz, J.F.; Mendoza, J.M.F.; Aznar-Sanchez, J.A.; Gallego-Schmid, A. Circular economy implementation in the agricultural sector: Definition, strategies and indicators. Resour. Conserv. Recycl. 2021, 170, 105618. [CrossRef]

9. Pedro-Monzonís, M.; Solera, A.; Ferrer, J.; Estrela, T.; Paredes-Arquiola, J. A review of water scarcity and drought indexes in water resources planning and management. J. Hydrol. 2015, 527, 482-493. [CrossRef]

10. Mancosu, N.; Snyder, R.L.; Kyriakakis, G.; Spano, D. Water scarcity and future challenges for food production. Water 2015, 7, 975-992. [CrossRef]

11. Aznar-Sánchez, J.A.; Piquer-Rodríguez, M.; Velasco-Muñoz, J.F.; Manzano-Agugliaro, F. Worldwide research trends on sustainable land use in agriculture. Land Use Pol. 2019, 67, 104069. [CrossRef]

12. Maxwell, S.L.; Fuller, R.A.; Brooks, T.M.; Watson, J.E.M. Biodiversity: The ravages of guns, nets and bulldozers. Nature 2016, 536, 143-145. [CrossRef] [PubMed]

13. Kissinger, G.; Herold, M.; De Sy, V. Drivers of Deforestation and Forest Degradation: A Synthesis Report for REDD+ Policymakers; Lexeme Consulting: Vancouver, BC, Canada, August 2012. Available online: https://www.cifor.org/knowledge/publication/5167/ (accessed on 25 July 2021).

14. Forouzani, M.; Karami, E. Agricultural water poverty index and sustainability. Agron. Sustain. Dev. 2011, 31, 415-432. [CrossRef]

15. Velasco-Muñoz, J.F.; Aznar-Sánchez, J.A.; Batlles-delaFuente, A.; Fidelibus, M.D. Sustainable Irrigation in Agriculture: An Analysis of Global Research. Water 2019, 11, 1758. [CrossRef]

16. Aznar-Sánchez, J.A.; Velasco-Muñoz, J.F.; Belmonte-Ureña, L.J.; Manzano-Agugliaro, F. The worldwide research trends on water ecosystem services. Ecol. Indic. 2019, 99, 310-323. [CrossRef] 
17. Aznar-Sánchez, J.A.; Belmonte-Ureña, L.J.; Velasco-Muñoz, J.F.; Manzano-Agugliaro, F. Economic analysis of sustainable water use: A review of worldwide research. J. Clean. Prod. 2018, 198, 1120-1132. [CrossRef]

18. Adeyemi, O.; Grove, I.; Peets, S.; Norton, T. Advanced monitoring and management systems for improving sustainability in precision irrigation. Sustainability 2017, 9, 353. [CrossRef]

19. Cunningham, S.A.; Attwood, S.J.; Bawa, K.S.; Benton, T.G.; Broadhurst, L.M.; Didham, R.K.; McIntyre, S.; Perfecto, I.; Sam-ways, M.J.; Tscharntke, T.; et al. To close the yield-gap while saving biodiversity will require multiple locally relevant strate-gies. Agric. Ecosyst. Environ. 2013, 173, 20-27. [CrossRef]

20. Fu, H.Z.; Wang, M.H.; Ho, Y.S. Mapping of drinking water research: A bibliometric analysis of research output during 1992-2011. Sci. Total Environ. 2013, 443, 757-765. [CrossRef]

21. UNESCO. UN-Water, 2020: United Nations World Water Development Report 2020: Water and Climate Change, Paris, UNESCO. Available online: https:/ / unesdoc.unesco.org/ark:/48223/pf0000372985/PDF/372985eng.pdf.multi (accessed on 25 July 2021).

22. Ochoa-Noriega, C.A.; Velasco-Muñoz, J.F.; Aznar-Sánchez, J.A.; Mesa-Vázquez, E. Overview of Research on Sustainable Agriculture in Developing Countries. The Case of Mexico. Sustainability 2021, 13, 8563. [CrossRef]

23. Ochoa-Noriega, C.A.; Aznar-Sánchez, J.A.; Velasco-Muñoz, J.F.; Álvarez-Bejar, A. The Use of Water in Agriculture in Mexico and Its Sustainable Management: A Bibliometric Review. Agronomy 2020, 10, 1957. [CrossRef]

24. Food and Agricultural Organization of the United Nations. El sistema Alimentario en México-Oportunidades Para el Campo Mexicano en la Agenda 2030 de Desarrollo Sostenible; FAO: Ciudad de México, Mexico, 2019. Available online: http://www.fao.org/3/CA291 OES/ca2910es.pdf (accessed on 25 July 2021).

25. Food, Agricultural and Fisheries Information Service. 2019 Food E Agriculture Overview; SIAP: Mexico City, Mexico, 2019 Available online: https:/ / nube.siap.gob.mx/gobmx_publicaciones_siap/pag/2019/Agricultural-Atlas-2019 (accessed on 21 July 2021).

26. World Trade Organization. World Trade Statistical Review. 2019. Available online: https://www.wto.org/english/res_e/statis_ e/wts2019_e/wts19_toc_e.htm (accessed on 21 July 2021).

27. Dyer, G.A.; Hernández-Solano, A.; Meza-Pale, P.; Robles-Berlanga, H.; Yúnez-Naude, A. Mexican agriculture and policy under NAFTA. In Serie Documentos de Trabajo del Centro de Estudios Económicos 2018-04; El Colegio de México, Centro de Estudios Económicos: Mexico City, Mexico, 2018.

28. Garduño-Rivera, R. Regional Economic Development in Mexico: Past, Present, and Future. In NAFTA's Impact on Mexico's Regional Development; New Frontiers in Regional Science: Asian, Perspectives; De León-Arias, A., Aroca, P., Eds.; Springer: Singapore, 2021; Volume 51. [CrossRef]

29. Sosa-Baldivia, A.; Ruíz-Ibarra, G. Food availability in Mexico: An analysis of agricultural production over the last 35 years and its projection for 2050. Pap. Poblac. 2017, 23, 207-230. Available online: https://rppoblacion.uaemex.mx/article/view/9111 (accessed on 25 July 2021).

30. The World Bank. 2021. Available online: https://data.worldbank.org/indicator/SL.AGR.EMPL.ZS?end=2019\&locations=MX\& start=1991 (accessed on 21 July 2021).

31. Oficina de la Presidencia de la República y Secretario Ejecutivo del Consejo Nacional de la Agenda 2030 para el Desarrollo Sostenible. Informe Nacional Voluntario para el Foro Político de Alto Nivel sobre Desarrollo SOSTENIBLE 2018. Bases y Fundamentos en México Para Una Visión del Desarrollo Sostenible a Largo Plazo. Avance en el cumplimiento de la Agenda 2030 y los Objetivos de Desarrollo Sostenible. Available online: http://www.agenda2030.mx/docs/doctos/InfNalVol_FPAN_DS_2018 _es.pdf (accessed on 4 August 2021).

32. Carrasco-Quintero, M.R.; Ortiz-Hernández, L.; Roldán-Amaro, J.A.; Chávez-Villasana, A. Desnutrición y desarrollo cognitivo en infantes de zonas rurales marginadas de México. Gac. Sanit. 2016, 30, 304-307. [CrossRef]

33. Solovieva, Y.; Quintanar, R.; Lázaro, G. Efectos socioculturales sobre el desarrollo psicológico y neurológico en niños preescolares. Cuad. Hispanoam. Psicol. México 2006, 6, 9-20.

34. Comisión Nacional del Agua (CONAGUA). Estadísticas Agrícolas de los Distritos de Riego, Año Agrícola 2017-2018; CONAGUA: México D.F., Mexico, 2019. Available online: https:// files.conagua.gob.mx/conagua/publicaciones/Publicaciones/EAUR_2017 -2018.pdf (accessed on 4 August 2021).

35. Bracamonte, A.; Valle, N.; Méndez, R. La nueva agricultura sonorense: Historia reciente de un viejo negocio. Región Soc. 2007, 19, 51-70. [CrossRef]

36. Secretaría de Agricultura, Ganadería, Recursos Hidráulicos, Pesca y Acuacultura (SAGHARPA). Programa Sectorial de Mediano Plazo de Agricultura, Ganadería, Recursos Hidráulicos, Pesca y Acuicultura 2016-2021. Hermosillo, Mexico. 2016. Available online: http:/ / sagarhpa.sonora.gob.mx/portal_sagarhpa/images/archivos/PMP/PSMPAGRHPAPART1.pdf (accessed on 4 August 2021).

37. Camarena-Gómez, B.O.; Ochoa-Nogales, C.B.; Valenzuela-Quintanar, A.I. Comunicación y percepción del riego por compuestos orgánicos persistentes en jornaleros agrícolas de Sonora, México. POLIS Rev. Latinoam. 2014, 13, 275-300.

38. Bravo-Pérez, H.M.; Castro-Ramírez, J.C.; Magaña-Zamora, J.D.; Reyes-Martínez, A. Evaluación de políticas alternativas de suministro de agua en Hermosillo, Sonora, México. Tecnol. Cien. Agua 2013, 4, 163-169. Available online: http:/ /www.scielo.org. $\mathrm{mx}$ /scielo.php?script=sci_arttext\&pid=S2007-24222013000200011 (accessed on 25 July 2021).

39. Martínez-Peralta, C.M.; Moreno-Vázquez, L.M. Análisis de diseño institucional de las reglas génesis de la Asociación de Usuarios del DR 051-Costa de Hermosillo. Estud. Soc. 2016, 47, 41-69. 
40. Moreno-Vázquez, J.L. Por Debajo del Agua. In Sobreexplotación y Agotamiento del Acuífero de la Costa de Hermosillo, 1945-2005; El Colegio de Sonora: Hermosillo, Mexico, 2005; p. 507. ISBN 9686755551.

41. Martínez-Peralta, C.M. El Dilema de los Comunes en la Gran Irrigación El Caso del Acuífero de la Costa de Hermosillo, Sonora, México, 1970-2010. Ph.D. Thesis, Colegio de Sonora (COLSON), Hermosillo, Mexico, 2014.

42. Pérez-López, E.P. Los Sobrevivientes del Desierto: Producción y Estrategias de Vida Entre los Ejidatarios de la Costa de Hermosillo, Sonora (1932-2010). Ph.D. Thesis, UAM-Xochimilco, México City, Mexico, 2011.

43. Diario Oficial. Ley de Aguas Nacionales. Secretaría de Agricultura y Recursos Hidráulicos. 1992. Available online: http: //www.diputados.gob.mx/LeyesBiblio/ref/lan/LAN_orig_01dic92_ima.pdf (accessed on 4 August 2021).

44. Lastiri-Hernández, M.A.; Álvarez-Bernal, D.; Moncayo-Estrada, R.; Cruz-Cárdenas, G.; Silva García, J.T. Adoption of phytodesalination as a sustainable agricultural practice for improving the productivity of saline soils. Environ. Dev. Sustain. 2021, 23, 8798-8814. [CrossRef]

45. Ramırez-Arias, A.; Campos-Salazar, V.; Pineda-Pineda, J.; Fitz-Rodriguez, E. Analysis of energy consumption for tomato production in low technology greenhouses of Mexico. Acta Hortic. 2020, 1296, 753-758. [CrossRef]

46. Diaz-Garza, A.M.; Fierro-Rivera, J.I.; Pacheco, A.; Schüßler, A.; Gradilla-Hernández, M.S.; Senés-Guerrero, C. Temporal Dynamics of Rhizobacteria Found in Pequin Pepper, Soybean, and Orange Trees Growing in a Semi-arid Ecosystem. Front. Sustain. Food Syst. 2020, 419, 602283. [CrossRef]

47. Gutiérrez-Moreno, M.; Sánchez-Atondo, A.; Mungaray-Moctezuma, A.; Salazar-Briones, C. Sustainability prospective for water resources in Northwestern Mexico: Use of recycled concrete for Agricultural purpose water supply. Interciencia 2020, 45, 370-377.

48. Pérez-Valladares, C.X.; Moreno-Calles, A.I.; Casas, A.; Rangel-Landa, S.; Blancas, J.; Caballero, J.; Velazquez, A. Ecological, cultural, and geographical implications of Brahea dulcis (Kunth) Mart. insights for sustainable management in Mexico. Sustainability 2020, 12, 412. [CrossRef]

49. Pérez, G.; Islas, J.; Guevara, M.; Suárez, R. The sustainable cultivation of Mexican nontoxic Jatropha curcas to produce biodiesel and food in marginal rural lands. Sustainability 2019, 11, 5823. [CrossRef]

50. Padilla-Bernal, L.E.; Lara-Herrera, A.; Vélez-Rodríguez, A.; Loureiro, M. Sustainability and environmental management in the Mexican vegetable sector. Acta Hortic. 2019, 1258, 163-170. [CrossRef]

51. Díaz-José, J.; Guevara-Hernandez, F.; Rodríguez-Larramendi, L.A.; Nahed-Toral, J.; Pinto-Ruiz, R.; Coss, A.L.; Aguirre-López, J.M. Vulnerability, innovation and social resilience in the maize (Zea mays L.) production: The case of the conservation tillage club of Chiapas, Mexico. Trop. Subtrop. Agroecosyst. 2018, 21, 399-408.

52. León, A.; Agustin, A.; Sulvaran, J. The myth behind sustainable african palm crop. Socio-environmental impacts of palm oil in Chiapas, Mexico. Int. J. Ecol. Dev. 2017, 32, 1-19.

53. Vallejo-Ramos, M.; Moreno-Calles, A.I.; Casas, A. TEK and biodiversity management in agroforestry systems of different socio-ecological contexts of the Tehuacán Valley. J. Ethnobiol. Ethnomed. 2016, 12, 31. [CrossRef]

54. García, L.B.; Dávila, J.P.; Acosta, F.O.; Lizán, S.S.; Acuña, I.J.; López, F.G. Degree of sustainability of rural development in subsistence, intermediate, and comercial farmers, under an autopoietic view point. Rev. Cient. 2009, 19, 650-658.

55. Wisser, D.; Frolking, S.; Douglas, E.M.; Fekete, B.M.; Schumann, A.H.; Vörösmarty, C.J. The significance of local water resources captured in small reservoirs for crop production-A global-scale analysis. J. Hydrol. 2010, 384, 264-275. [CrossRef]

56. Queirós, A.; Faria, D.; Almeida, F. Strengths and limitations of qualitative and quantitative research methods. Eur. J. Educ. Stud. 2017, 3, 369-387. [CrossRef]

57. Kuntosch, A.; König, B.; Bokelmann, W.A. Systemic Perspective to Horticultural Innovation-The Case of Energy Saving Innovations in German Horticulture Proc. II International Symposium on Horticulture in Europe ed J-C Mauget and S Godet. Acta Hortic. 2015, 1099, 503-510. [CrossRef]

58. Comisión Nacional del Agua (CONAGUA, 2020). Actualización de la Disponibilidad Media anual de Agua en el Acuífero Costa de Hermosillo (2619) Estado de Sonora 2020. Subdirección General Técnica, Gerencia de Aguas Subterráneas. Comisión Nacional del Agua: México D.F., Mexico. Available online: https://sigagis.conagua.gob.mx/gas1/Edos_Acuiferos_18/sonora/DR_2619.pdf (accessed on 6 August 2021).

59. Díaz-Caravantes, R.E.; Bravo-Peña, L.C.; Alatorre-Cejudo, L.C.; Sánchez-Flores, E. Presión antropogénica sobre el agua subterránea en México: Una aproximación geográfica. Investig. Geográficas 2013, 82, 93-103. Available online: http:/ /www.scielo.org. $\mathrm{mx}$ /scielo.php?pid=S0188-46112013000300007\&script=sci_abstract (accessed on 25 July 2021). [CrossRef]

60. Olavarrieta-Carmona, M.V. Beneficios de la cuota energética. Estudio de caso de la Costa de Hermosillo, Sonora, México, 2006-2007. Región Soc. 2010, 22, 146-164. Available online: http://www.scielo.org.mx/scielo.php?script=sci_arttext\&pid=S187039252010000100007 (accessed on 25 July 2021). [CrossRef]

61. Hernández-Pérez, J.L. Los Cambios en el Patrón de Cultivos en Sonora a Partir del Proceso de Restauración Agrícola en México: El Caso de la Costa de Hermosillo. Master's Thesis, Centro de Investigación en Alimentación y Desarrollo (CIAD), Hermosillo, Mexico, 2012

62. Manzanares-Rivera, J.L. Calidad de los recursos hídricos en el contexto de la actividad económica y patrones de salud en Sonora, México. Salud Colect. 2016, 12, 397-414. [CrossRef]

63. Flick, U. Designing Qualitative Research; SAGE Publications Ltd.: New York, NY, USA, 2007; ISBN 9780761949763. [CrossRef]

64. Grant, M.J.; Booth, A. A typology of reviews: An analysis of 14 review types and associated methodologies. Health Inf. Libr. J. 2009, 26, 91-108. [CrossRef] 
65. Velten, S.; Leventon, J.; Jager, N.; Newig, J. What is sustainable agriculture? A systematic review. Sustainability 2015, 7, 7833-7865. [CrossRef]

66. Reiter, B. Theory and Methodology of Exploratory Social Science Research. Int. J. Soc. Res. Methodol. 2017, 5, 129-150. Available online: http:/ / scholarcommons.usf.edu/gia_facpub/132 (accessed on 25 July 2021).

67. Qu, S.Q.; Dumay, J. The qualitative research interview. Qual. Res. Acc. Manag. 2011, 8, 238-264. [CrossRef]

68. Næss, P. Validating explanatory qualitative research: Enhancing the interpretation of interviews in urban planning and transportation research. Appl. Mobilities 2018, 5, 186-205. [CrossRef]

69. Rosenthal, M. Qualitative research methods: Why, when, and how to conduct interviews and focus groups in pharmacy research. Curr. Pharm. Teach. Learn. 2016, 8, 509-516. [CrossRef]

70. DiCicco-Bloom, B.; Crabtree, B.F. The qualitative research interview. Med. Educ. 2006, 40, 314-321. [CrossRef]

71. Ahmed, S.; Asraf, R.M. The workshop as a qualitative research approach: Lessons learnt from a "critical thinking through writing" workshop. Turk. Online J. Des. Art Commun. 2018, September 2018 Special Edition, 1504-1510. [CrossRef]

72. MacMillan, D.C.; Marshall, K. The Delphi process-An expert-based approach to ecological modelling in data-poor environments. Anim. Conserv. 2006, 9, 11-19. [CrossRef]

73. Coleman, S.; Hurley, S.; Koliba, C.; Zia, A. Crowdsourced Delphis: Designing solutions to complex environmental problems with broad stakeholder participation. Glob. Environ. Chang. 2017, 45, 111-123. [CrossRef]

74. Oreszczyn, S.; Carr, S. Improving the link between policy research and practice: Using a scenario workshop as a qualitative research tool in the case of genetically modified crops. Qual. Res. 2008, 8, 473-497. [CrossRef]

75. Organización de las Naciones Unidas para la Agricultura y la Alimentación. Captación y Almacenamiento de Agua de LluviaOpciones Técnicas Para la Agricultura Familiar en América Latina y el Caribe; FAO: Santiago, Chile, 2013; ISBN 978-92-5-307580-5.

76. Velasco-Muñoz, J.F.; Aznar-Sánchez, J.A.; Batlles de la Fuente, A.; Fidelibus, M.D. Rainwater harvesting for agricultural irrigation: An analysis of global research. Water 2019, 11, 1320. [CrossRef]

77. Aznar-Sánchez, J.A.; Belmonte-Ureña, L.J.; Velasco-Muñoz, J.F.; Valera, D.L. Aquifer sustainability and the use of desalinated seawater for greenhouse irrigation in the Campo de Nijar, Southeast Spain. Int. J. Environ. Res. Public Health 2019, 16, 898. [CrossRef]

78. Carrillo-Huerta, M.M.; Gómez-Bretón, E. La tecnología en el uso sustentable del agua para riego en México. El caso del acuífero de Tecamachalco, Puebla, 2017. Panor. Econ. 2020, 15, 27-56. [CrossRef]

79. Dévora-Isiordia, G.E.; López, M.; Fimbres, G.; Álvarez, J.; Astorga, S. Desalación por ósmosis inversa y su aprovechamiento en la agricultura en el valle del Yaqui, Sonora, México. Tecnol. Cien. Agua 2016, 3, 155-169. Available online: http:/ /www.scielo.org. $\mathrm{mx}$ /scielo.php?script=sci_arttext\&pid=S2007-24222016000300155 (accessed on 25 July 2021).

80. Dévora-Isiordia, G.E.; González-Enríquez, R.; Ruiz-Cruz, S. Evaluación de procesos de desalinización y su desarrollo en México. Tecnol. Cienc. Agua 2013, 4, 27-46.

81. Cooley, H.; Phurisamban, R. The Cost of Alternative Water Supply and Efficiency Options in California. Pacific Institute: Oakland, CA, USA, 2016; ISBN 978-1-893790-75-9.

82. Loera-Alvarado, L.A.; Torres-Aquino, M.; Martínez-Montoya, J.F.; Cisneros-Almazán, R.; Martínez-Hernández, J.J. Calidad del agua de escorrentía para uso agrícola captada en bordos de almacenamiento. Ecosistemas Recur. Agropecu. 2019, 6, $283-295$. [CrossRef]

83. López-Hernández, N.A.; Palacios-Vélez, O.L.; Anaya-Garduño, M.; Chávez-Morales, J.; Rubiños-Panta, J.E.; García-Carrillo, M. Diseño de sistemas de captación del agua de lluvia: Alternativa de abastecimiento hídrico. Rev. Mex. Cienc. Agríc. 2017, 8, 1433-1439. Available online: http:/ / www.scielo.org.mx/scielo.php?script=sci_arttext\&pid=S2007-09342017000601433\&lng= es\&tlng=es (accessed on 25 July 2021). [CrossRef]

84. Villa-Rodríguez, A.O.; Bracamonte-Sierra, A. Procesos de aprendizaje y modernización productiva en el agro noroeste de México: Los casos de la agricultura comercial de la Costa de Hermosillo, Sonora y la agricultura orgánica de la zona sur de Baja California Sur. Estud. Front. 2013, 27, 217-254. Available online: http:/ / www.scielo.org.mx/scielo.php?script=sci_arttext\&pid=S0187-6961 2013000100008 (accessed on 25 July 2021). [CrossRef]

85. Yáñez-Quijada, A.I.; Camarena-Gómez, B.O. Salud ambiental en localidades agrícolas expuestas en plaguicidas en Sonora. Soc. Ambiente 2019, 7, 55-82. [CrossRef]

86. Aznar-Sánchez, J.A.; Belmonte-Ureña, L.J.; Velasco-Muñoz, J.F.; Valera, D.L. Farmers' profiles and behaviours toward desalinated seawater for irrigation: Insights from South-east Spain. J. Clean. Prod. 2021, 296, 126568. [CrossRef]

87. Gobierno de Sonora. Desaladora Sonora. Available online: https://desaladora.sonora.gob.mx/ (accessed on 2 December 2021). 